Olena Konoplina

Kyiv National University of Culture and Arts

\title{
Dominant features of the historical interiors of the mosques of Persia and the Maghreb countries
} Dominujące właściwości historycznych wnętrz meczetów w krajach perskich i maghrebskich

\begin{abstract}
This article identifies specific features of the interiors of the mosques of Persia and Maghreb which embody the best artistic achievements of different times. The relevance of this topic is connected with the fashion for the use of modernised oriental motifs in modern architecture. Examples of ornamental finishing of mosques of Persia and the Maghreb countries illustrate two opposite approaches to decorating and interior design, which originally developed in mosques from a single prototype - the Arabic hypostyle mosque.
\end{abstract}

Keywords: interior decoration, interior design, specific features, mosques of Persia and Maghreb

\section{Streszczenie}

Artykuł określa specyficzne szczegóły wnętrz meczetów krajów perskich i maghrebskich, zawierające najwybitniejsze osiągnięcia artystyczne pochodzące z różnych czasów. Aktualność tego tematu jest związana z modą na wykorzystanie zmodernizowanych wschodnich wątków we współczesnej architekturze. Na przykładzie dekoracji meczetów Persji i Maghrebu zilustrowano dwa przeciwne podejścia do dekoracji i rozwiązania wyposażenia przestrzeni wewnętrznych, które niegdyś w meczetach rozwinęły się ze wspólnego pierwowzoru - arabskiego meczetu z filarami.

Słowa kluczowe: dekoracje wnętrz, projektowanie wnętrz, specyficzne szczegóły, meczety Persji i Maghrebu 


\section{INTRODUCTION}

Despite the existence of a persuasive primary source base, especially that which concerns the history of Persian architecture (the architecture of the Maghreb countries is less known), the issue of interior decoration is less researched than both the history of construction and the history of architecture descriptions; and the issue of interior decoration and interior elements is, as a rule, only mentioned within the sphere of architecture in its entirety. This is why it has become necessary, on the basis of the existing source base, to focus on the decoration of interiors using examples of historical mosques. Today, in many countries, the fashionable trend of using stylised oriental motifs is spreading. The issue is that often, architects and designers do not have the necessary knowledge and combine elements of many styles of the Islamic world in one room at once, which leads to a lack of integrity of the interior design.

In order to objectively assess the specific techniques of mosque decoration in these two countries, the method of system-structural analysis was applied; such an analysis is based on comparison of the same features (for example, arches with arches, columns with columns, ornaments with ornaments). This method was applied in the research works of O. Shkolna'; M. Dyomin, M. Orlenko, Yu. Ivashko ${ }^{2}$, post-graduate students Zahedi Shahab ${ }^{3}$ and Rezga Kouider ${ }^{4}$. Over the past five years, O. Shkolna has performed research of Ukrainian-Persian and Ukrainian-Turkish ties in the context of domestic 'persiiarnias', resulting in the monograph Great Public Manufactures of Princes Radziwill of the $18^{\text {th }}$ and $19^{\text {th }}$ Centuries in Eastern Europe. In parallel, she studied individual collections of Persian ceramics and porcelain in Azerbaijan and Iran, and compared the architecture of the traditional Moroccan buildings with the mirror interiors of Iran of the $19^{\text {th }}-21^{\text {st }}$ centuries.

In numerous publications by M. Dyomin, Zahedi Shahab, Yulia Ivashko and Rezga Kouider, the inner spaces of the mosques of Persia and Algeria have been thoroughly investigated.

\section{THE ARCH AS A DISTINCTIVE ELEMENT OF THE INTERIOR}

One of the most distinctive elements of the oriental interior is the arch; the arch of foremost importance is that which is over the niche of the mihrab, the holiest place in the mosque. In Persia and Algeria (as well as in Morocco), specific forms of arches were used in the interiors of mosques ${ }^{5}$. In Persia, the list of types of arches used is not as developed (as a rule, these are various modifications of pointed arches) as it is in Algeria. This is explained by the fact that the constructive scheme was more complicated - they developed structures of domes, whereas the mosques of Algeria and of the Maghreb countries were entirely of defensive origin and historically had no domes at all (except for the later Ottoman-type mosques). Such noticeable differences become clear if we analyse the origins of the Islamic 
architecture of these two countries - from the palace apadanas and Zoroastrian Pavilion 'Chartak' in Persia and from the fortification buildings of the Maghreb military dynasties in the Maghreb countries. Initially, this caused the difference in approaches to the decoration of the interiors of mosques - in Persia, during the Safavids period, the interior actually turns into solid planes of decor, where even the constructive elements had the character of decoration. In the Maghreb countries, there was no tradition of intense decoration, and although the interiors also gradually become more decorated, they are however noticeably more reserved. In Algeria, the primary attention was paid not to decorating, but to the functionality and simple geometry of shapes, subordinate to the proportional relationship and mathematical calculations.

Therefore, the focus in the interiors of the mosques of Algeria was given to experimenting with a purified geometric shape and not with its decoration. In particular, based on the analysis of common shapes of arches, Rezga Kouider has classified eleven principal types: semi-circular; Ottoman-type segmented arch (otherwise, an understated arch, an arch with a small boom); pointed; ovate; horseshoe-shaped (so-called Maghreb); semi-elliptical; shell-shaped; curvilinear with acute angle at the top (the so-called Persian or Iranian); composite with rectangular protrusions; multifoil arch of several small arches; or scalloped composite with vertical columnar appearances. This list deliberately excludes specific types of arches of the Kharijites mosques ${ }^{6}$.

The roots of various types of arches are: a semi-circular arch from the Umayyad Mosque in the city of Damascus; a segmental arch of the so-called Ottoman type, from the Ottoman Empire; a pointed arch from the Dome of the Rock in Al-Quds and the mosque of Ibn Tulun, Cairo; a horseshoe arch, the so-called Maghreb from the Umayyad Mosque in Damascus; a curved arch with an acute angle at the top (the so-called Iranian) from Persia.

Regional types of arches for the countries of the Maghreb are: ovate; horseshoe (the so-called Maghreb); shell-shaped; multifoil of several small arches or festoon; arches of the Kharijite mosques - semi-circular geometrically regular or rampant, lancet and pointed horseshoe type.

In Algeria, such a variety of arches in the interiors is also associated with numerous external influences in combination with local traditions. In particular, on the basis of identifying the distribution of various types of arches, the horseshoe-shaped Maghreb, semi-circular, pointed, shell-shaped (mihrab arch) were noted as the principal types. Unlike Persia, where mosques were decorated everywhere inside and outside, the decor in the interiors of mosques in Algeria was used fragmentarily, as a rule, the planes around the arch of the mihrab and the arch of the mihrab were decorated. Despite the fact that a horseshoe arch was borrowed from Damascus, it spread under the name of the Maghreb arch.

The European Baroque style is a version of arch that originates from a shell-shaped arch of the mihrab (the Portuguese word 'baroque' literally means 'unevenly shaped pearls'). In addition, the lack of decor in the interiors of the Maghreb mosques provided them with too simple and diverse forms of elements. The facades were simple and almost devoid of decor. 


\section{COLUMNS AND BEARING PILLARS IN INTERIORS}

A canon for many mosques of the Maghreb countries at the early stage of Islam was the Sidi Okba mosque in Kairouan (Tunisia), where 180 columns of Roman and Byzantine buildings, dismantled for this purpose, were used alongside the massive fortification architecture. Because the orders were various, columns with different capitals were used simultaneously in the interior, and this gradually led to another specific Maghreb tradition - the simplification of the ancient order and the formation on the basis of their own capitals of the times of different dynasties. In addition, the Grand Mosque of Cordoba became the standard for the Maghreb mosques, where each cell of the interior is formed by two columns with an arch based on a mathematical construction and different types of columns from dismantled Roman and Byzantine buildings are also used simultaneously. In the Great Mosque of Cordoba, the principle of modification of the ancient order and the simultaneous use of different materials in the order was also apparent; marble could be of different colours - porphyry, granite, gem jade, white and red bricks were also combined with marble. A certain 'barbarisation' of the order of Ancient Rome took place, and on its basis the order of the times was created of the rule of Zirids (where the top row leaves were stylised); of the Hammadids period (where the volutes were stylised); of the Almoravids period (where the upper rows were a part of the Doric order and the lower part were from the Corinthian order); of the Almohad dynasty period (where the Ionic and Corinthian orders were combined); of the Abdalvadids period (where the Doric and Corinthian orders were joined); of the Merinids period (where the meander was applied); of the Hafsids period (with a round base and square crowning); the Ottomans period (where the lon order was stylised). The columns themselves were of different shapes - circular, square, cross, T-shaped, octagonal. Rezga Kouider defined the following forms of capitals: cylindrical, conical, five-pointed, helical, octagonal. In the early periods, massive load-bearing columns without bases and capitals were used with horseshoe-shaped Maghreb arches supported on them.

At the same time, during the period of Ottoman rule in Algeria, the arches and the bearing supports of the interior become simpler and more uniform, but more of their decoration appears.

\section{TYPES OF DECORATIVE FINISHES}

The specificity of Islamic decor is the replacement of anthropomorphic and zoomorphic ornament with geometric and phitomorphic ornament. According to the existing version, not only the pointed Gothic arch, but also the Gothic rosette is of Islamic origin from the Umayyad Palace in Khirbat al-Mafjar in Jordanian Valley (740-750). Two Islamic schools Shiite Persian and Sunni Maghreb - have developed opposite approaches to the means of decorating the interiors of mosques. If in Persia and territories exposed to Persian influences (like Central Asia) all planes and structural elements at the stage of high development are transformed into a decorated carpet with bright polychrome, then the decor of the Maghreb school is discreet, monochrome or polychrome with a limited number of colours. 
In the Persian Islamic school at various periods of development, a variety of decoration methods were introduced. During the Abbasids period, the most common was the carved white knock, which was used to decorate the inner surfaces of the interior. Walls, architectural details and sculptural decoration after polishing created an imitation of marble; later they began to apply polychrome coloured stucco ornament. During the Seljuki rule, there was a modification of the stucco ornament, which becomes a fragile patchwork with monochrome and polychrome phytomorphic ornamentation carved on the surface of the brickwork. During the Achaemenid period, glazed inlay appears in blue and dark blue. Carved wooden décor was rarely used. Non-decorative white alabaster plastering of the surfaces of mosque interiors have been widely used since about the $16^{\text {th }}$ century ${ }^{7}$. During the rule of the Abbasids, the focus was on decorating exteriors and interiors; various decorative techniques emerged and developed. Carved stucco on the interior surfaces (various types of polychrome and monochrome carving), and later polychrome-glazed white and bluegreen tiles, geometric glaze and phytomorphic ornamentation, and lustre facing tiles were widely used. In the period of the Abbasids rule, the use of glaze and glazed mosaic of stucco and terracotta with a predominance of white, blue and dark-blue colours acquired a special scope $^{8}$. In all periods, the ornaments in the interiors of the mosques of Persia were reduced to geometrical and phytomorphic ${ }^{9}$. Other decoration techniques were developed in the Maghreb countries.

White ornamental carved decor is most characteristic of the interiors of Algerian mosques of the Almoravids era (geometric or simplified phytomorphic ornament), mosaic floors; in the period of Abdalvadids (Zianids), complex carved and ceramic décor spread; in the Merinids period, the ornamentation of mosaic floors was complicated, the trend of the plastering of walls and ceramic tiles arose in the Ottomans era.

\section{CONCLUSION}

An overview of the specific features of the interiors of the mosques of Persia and Algeria has made it possible to formulate the basic principles of their solution for different periods. Thus, in the Islamic schools of the Maghreb, the focus was on mathematically verified proportions and the perfect combination of forms. In the Persian school, the main focus was gradually placed on the variety of planning decisions in the direction of their complexity, on the complication of volumetric and spatial compositions, and an increase in the volume and methods of decoration. This is a fundamental difference from the schools of the Maghreb, where the type of domeless Maghreb mosque remained without significant changes during all the ruling dynasties. In the Persian school, enamelled ceramics and carving works play a special part. The interiors of the Maghreb school seem simpler, but mathematically verified, and modified Roman orders have a special place. Understanding the specifics of the stylistic construction of the interiors of the Persian and Maghreb schools enables the avoidance of mistakes when designing modern interiors that are oriental in style. 


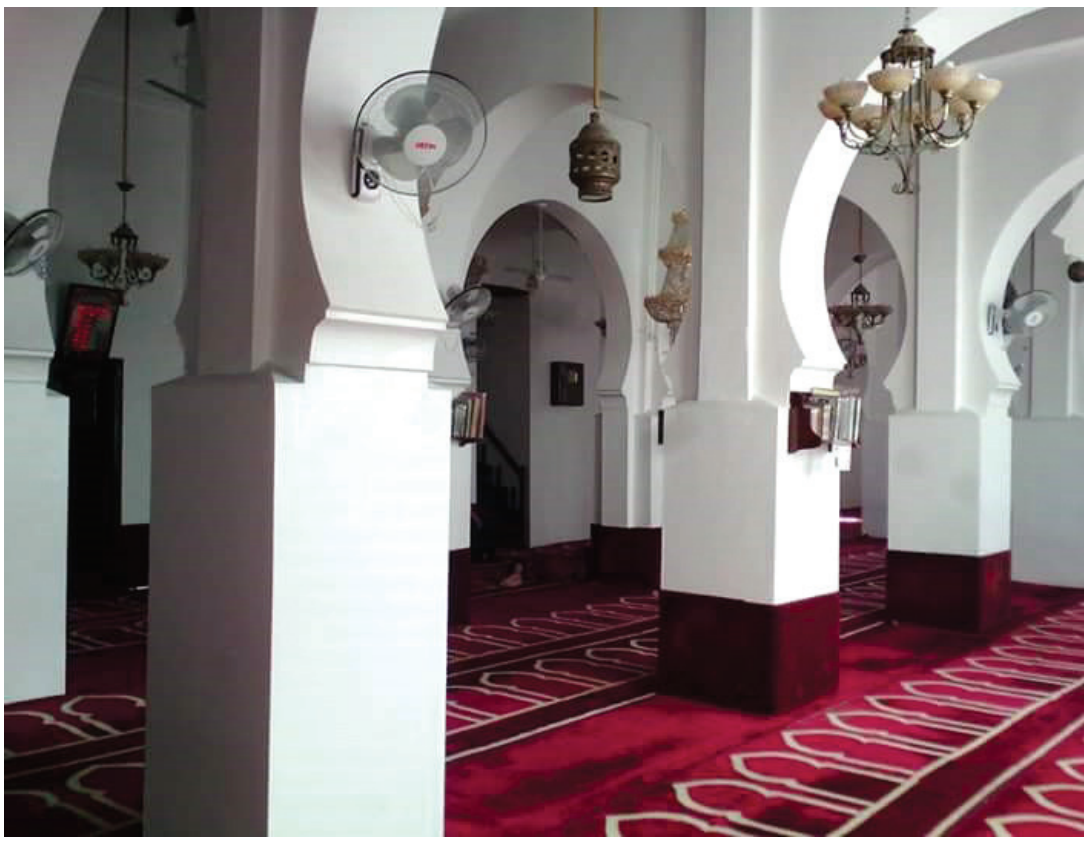

III. 1. The interior of Djama'a al-Kebir of Nedroma, Maghreb type (photo by Rezga Kouider)

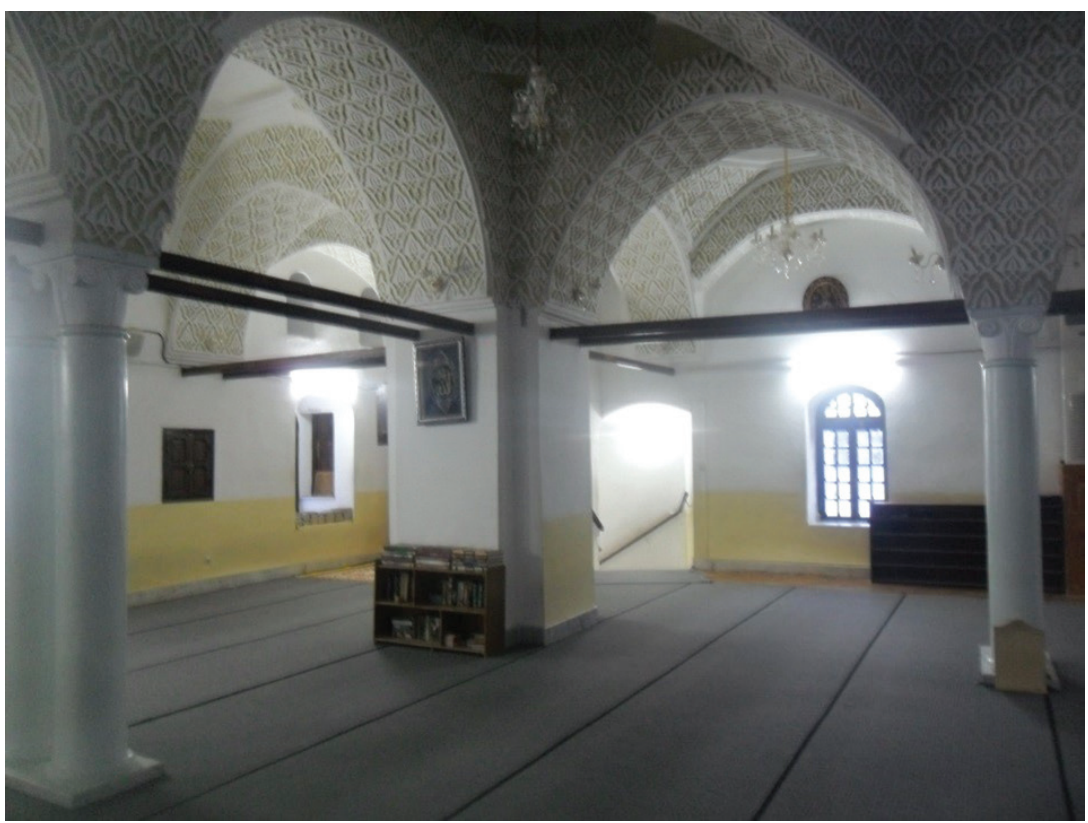

III. 2. The interior of the mosque Ali Bitchin of Algiers, Ottoman type (photo by Rezga Kouider) 


\section{PRZYPISY}

1 O. Shkolna, Artistic features of the Persian facing ceramics of Tebriz of the $18^{\text {th }}-19^{\text {th }}$ centuries, Australian Journal of Education and Science 2(16)/2015, 448-455; eadem, Persyiarnias of the ethnic Ukraine as a part of the Polish-Lithuanian Commonwealth of the $17^{\text {th }}$ the beginning of the twentieth centuries, Cambridge Journal of Education and Science 2(14)/2015, 304-310; eadem, Arabic art and today's specificity of its research study, Art culture, collection of research papers of Modern Art Research Institute of the National Academy of Arts of Ukraine, 13/2017, 119-127.

2 R. Kouider, Yu. Ivashko, Study Methodology of the Architectural Periodization of Algerian Mosques and the Ritual Role of Elements (Mihrab, Minbar, Qibla, Bath for Ablution) in the Islamic Worship Service, Woda i zieleń w architekturze. Środowisko Mieszkaniowe (Housing environment) 22/2018, 28-36.

3 Z. Shahab, The evolution of the architecture of mosques of Iran (VII-XVIII century), Kiev National University of Civil Engineering and Architecture, Kiev 2018.

4 R. Kouider, Yu. Ivashko, op. cit.; R. Kouider, Historic mosques of Ketchaoua, Djama'a al-Djedid and Djama'a al-Kebir in the Kasbah fortress in Algeria, current issues in research, conservation and restoration of historic fortifications, Chelm 2018, 10, 73-77; idem, National identity and external influences in the architecture of mosques of Algeria (11 ${ }^{\text {th }}$ century-1830), Kiev National University of Civil Engineering and Architecture, Kiev 2019.

5 Ibidem, p. 167.

6 Ibidem, pp. 167-172.

7 Z. Shahab, op. cit., p. 137.

8 Ibidem, pp. 138-139.

9 Ibidem, p. 140.

\section{REFERENCES}

Kouider R., Historic mosques of Ketchaoua, Djama'a al-Djedid and Djama'a al-Kebir in the Kasbah fortress in Algeria, current issues in research, conservation and restoration of historic fortifications, Chelm 2018, 10, 73-77.

Kouider R., National identity and external influences in the architecture of mosques of Algeria (11 ${ }^{\text {th }}$ century-1830), Kiev National University of Civil Engineering and Architecture, Kiev 2019.

Kouider R., Ivashko Yu., Study Methodology of the Architectural Periodization of Algerian Mosques and the Ritual Role of Elements (Mihrab, Minbar, Qibla, Bath for Ablution) in the Islamic Worship Service, Woda i zieleń w architekturze. Środowisko Mieszkaniowe (Housing environment) 22/2018, 28-36. 
Shahab Z., The evolution of the architecture of mosques of Iran (VII-XVIII century), Kiev National University of Civil Engineering and Architecture, Kiev 2018.

Shkolna O., Arabic art and today's specificity of its research study, Art culture, collection of research papers of Modern Art Research Institute of the National Academy of Arts of Ukraine, 13/2017, 119-127.

Shkolna O., Artistic features of the Persian facing ceramics of Tebriz of the $18^{\text {th }}-19^{\text {th }}$ centuries, Australian Journal of Education and Science 2(16)/2015, 448-455.

Shkolna O., Persyiarnias of the ethnic Ukraine as a part of the Polish-Lithuanian Commonwealth of the $17^{\text {th }}$ - the beginning of the twentieth centuries, Cambridge Journal of Education and Science 2(14)/2015, 304-310. 